\title{
Forbudte ord og billeder
}

af John T. Lauridsen

Junigrundloven 1849 gav trykkefrihed og i princippet ret til fri meningsdannelse, men det var en frihed under ansvar - naturligvis. Via lovgivningen havde (og har) myndighederne mulighed for og ret til at skride ind, hvis nogen forsynder sig mod den til enhver tid herskende offentlige moral, krænker privatlivets fred, er groft injurierende mod personer eller institutioner m.v. eller truer rigets sikkerhed og interesser. Tilsvarede havde og har privatpersoner, institutioner, firmaer m.v. ret til at gå til domstolene, hvis og når det trykte og/eller billeder efter deres opfattelse er gået deres interesser for nær. Ligeledes har det været muligt at beslaglægge udenlandske tryksager, som stred mod dansk lov. Igennem tiden har alle disse varianter af forbud været hævdet, og vil venteligt fremdeles blive det, selv om f. eks. både kønsmoralen og lovgivningen har flyttet sig og hele det politiske verdensbillede bliver forrykket.

De forbudte eller beslaglagte tryksager har efter ransagninger og evt. retsbehandling enten fundet vej til domstolenes og politiets arkiver eller - og det er ofte sket-er på Justitsministeriets anmodning i et eller flere eksemplarer tilstillet Det kongelige Bibliotek, som derfor rummer såvel tidligere forbudte skrifter som tryksager, hvortil offentligheden fremdeles ikke kan få adgang. Med få undtagelser findes dette materiale ikke samlet, men via Statstidende kan man danne sig et overblik over den litteratur, der er blevet forbudt gennem årene. Lånere vil også ved personligt at bladre i de gamle alfabetiske seddelkataloger på Det kongelige Bibliotek sjældne gange finde sedler med påskriften "Afleveret til Bruun", hvilket betyder, at det pågældende værk som forbudt var givet til overbibliotekar Chr. Bruun, som ledede biblioteket 
i årene 1863-1901. Eller der henvises på den alfabetiske seddel til at søge justitsministeriets tilladelse til benyttelse.

Almindeligvis vil alle de forbudte bøger fra forrige århundrede frem til 1945 nu være tilgængelige, men for tiden derefter opretholdes forbud mod en række skrifter fortsat. Nok er bibliotekets samlinger offentlige, men klausuler, forbud og testamentariske bestemmelser indskrænker for promiller af samlingernes vedkommende alligevel brugen.

\section{Håbløse forfattere - Litterær "pornografi"}

Forbud mod litterære værker har altid under folkestyret været omgærdet med stor opmærksomhed. I og med at grundloven hjemler politisk, religiøs såvel som kunstnerisk frihed, er netop juridiske anslag mod kunsten blevet heftigt debatteret, når den har fundet sted. Det tidligste af de berømte forbud mod et dansk litterært værk, gælder Herman Bangs Håbløse Slægter, 1880. Den blev forbudt i henhold til straffelovens ofte anvendte Paragraf 184 for at overskride sømmelighedens grænser i skildringen af William Høgs forhold til grevinde Hatzfeld. Det blev ved såvel politiretten som Højesteret takseret til en bøde på 100 kr. eller 14 dages fængsel. Bortset fra forbudet gav det Bang den berømmelse, som nok så mange forlagsannoncer og anmeldelser ikke kunne have givet, og den var forlængst udsolgt, før politiet skred til konfiskation. Bang var ikke selv i besiddelse af den forbudte bog, men mødte nogle år senere op på Det kongelige Bibliotek for at låne den, da han agtede at udgive en ny udgave. Overbibliotekar Chr. Bruun nægtede i første omgang Bang adgang til bogen med den begrundelse, at den nok eksisterede de facto, men ikke de jure. Hermed lod Bang sig ikke nøje, og efter en længere forhandling fik han lov til at låne sin egen roman til brug på læsesalen - i en time! I 1884 udkom så Håbløse Slægter påny, men uden de anstødelige partier, mens den originale udgave først blev trykt igen i 1965 - mange år efter forfatterens død.

Styrende for den litterære censur var beskrivelser eller optrin, som kunne virke pirrende eller anstødelige på læserne. Allerede titlerne kunne skærpe censorernes opmærksomhed, som den nu ret ukendte Martin Jørgensens Livsnydelse, 1885 eller den norske forfatter Hans Jægers Syk Kjærlighedt, 1893. I Hans Jægers tilfælde er det bemærkelsesværdigt, at hans 
øvrige bøger af samme kaliber, som bogen Kristiania-Bohemen ikke blev forbudt. Men også forfatteren selv kunne danne udgangspunkt for censorernes nærgående læsning, for hvorfor ellers falde over den unge vovede Gustav Wieds novelle under den uskyldige titel De ungeog de gamle i bladet København 27.12.1891? Når Edvard Brandes i sammeårti fik sin roman Det ungeblod, 1899, forbudt med henvisninger til siderne 92 og navnlig side 129, skyldes det måske mere den siddende regerings forsøg på at ramme en af sine skarpeste kritikere, snarere end en forargelig overskridelse af paragraf 184. Der var politisk gevinst i straks at få Brandes sværtet som pornograf i offentligheden.

Til andre tider kunne det knibe med hastigheden, før censuren fik sig taget sammen til at gribe ind. Emmy Carrell udgav i 1921 en bog med det i en mandsverden både opsigtsvækkende og egentligt overflødige spørgsmål Kan mænd undværes? Det kan de naturligvis ikke. Alligevel var der mange mænd -, som ville læse svaret, da det rummede ganske vist lidet originale beskrivelser af lesbiske kvinders omgang med hinanden. Bogen kom i fem oplag (!) før myndighederne skred ind, så succes'en var hjemme. I dag vil disse beskrivelser af lesbianisme ikke kunne støde en langt mere forhærdet offentlighed.

Den unge studenteraktivist og revolutionære Rudolf Broby Johansen satte på en helt anden måde bevidst og agressiv gang i debatten om kunstens udfoldelsesmuligheder under censurens blik i sit ekspressionistiske digte Blod, udsendt af Studentersamfundet i 1922. Digtsamlingen blev straks anstændigvis forbudt, og som professionel aktivist lod Broby ikke denne lejlighed gå fra sig for at slå et slag for ytringsfriheden, for kunsten - og for Broby. På den baggrund virker J. Anker-Paulsens samtidige - ligeledes forbudte - digte I badedragt og andre erotiske digte, 1922 trods titlen sært tamme. Ofte må vi regne med, at forfattere med fordel kunne spekulere i censurens reaktion.

\section{Beslagte udenlandske værker}

Lovgivningen gjaldt ikke kun dansk litteratur, men også den importerede fra udlandet, som faldt ind under de samme paragraffer. Foruden paragraf 184 var det paragraf 234. Nogle værker lod sig fange alene på titlen, som Erik Hoyer: Das lüsterne Weib. Sexualpsychologie der begehrenden, unbefriedigten und 
schamlosen Frau eller Jacques de Bandol: Perversitemoderne. De to titeleksempler kan måske også signalere noget om tysk og fransk mentalitet. Ofte skjuler der sig lærde og tørre afhandlinger bag sådanne titler, men det blev ikke taget så nøje. En del forbudt litteratur slap ind i landet uden om censuren og var til købs i boghandeler og antikvariater. Lejlighedsvise politirazziaer bragte nogle af uartighederne for dagen. Således var der en usædvanlig stor fangst ved et uanmeldt besøg i et københavnsk antikvariat i efteråret 1938. En lang række bøger blev bortført som pornografi og påfølgende beslaglagt ved en byretsdom i november. Censuren var temmelig lemfældig, og beslaglæggelsen kom til at omfatte værker af forfattere, som tidligere havde skrevet ganske lignende værker af samme karakter. Tilmed værker der var offentligt tilgængelige i Danmark. Sagen var ganske enkelt, at hvad der hos antikvaren blev fundet i en samling af pornografi også uden videre undersøgelser blev beslagt som pornografi uanset, at der ind imellem var tale om uhyre grundige og lærde værker, hvis forfattere i deres hjemlande med rette ville have kunne have følt sig forulempede over i Danmark at komme på listen over forbudt litteratur. Beslaglæggelserne var - naturligvis - med til at øge samlernes interesse, og priserne gik op derefter. En klassiker blandt samlere var Eduard Fuchs meget rigt illustrerede værk Illustrierte Sittengeschichte, 1909-12, som i 1940'erne havde nået en pris på 3-400 kr., hvilket var ganske mange penge dengang.

Beslaglæggelserne fortsatteopi efterkrigsårene. Ved en enkelt lejlighed i 1957 rykkede politiet ud på udenlandske myndigheders opfordring og konfiskerede ikke mindre end 6.603 udenlandske hæfter og 155 bøger. Blandt bøgerne var John Clelands klassiker Fanny Hill - Memoirs of a Woman of Pleasure, hvis 1. udgave var udkommet i 1749, men stadig mere end 200 år efter blev anset for så anstødelig, at den også blev konfiskeret ved en landsretsdom. Først efter en byrets-, landsrets- og højesteretsdom 1964-65 kunne Fanny Hill læses legalt i Danmark.

\section{Hensynet til fremmede magter}

har stedse spillet en betydelig rolle for skiftende danske regeringer og dermed for tolerancen overfor det trykte ord. Før NATO's oprettelse blev hensyn især vist overfor Tyskland, og siden 1949 i forhold til USA. Under 
første verdenskrig gik den danske regerings bestræbelser på at være neutrale mellem de krigsførende parter så vidt, at Politikens litteraturanmelder Kai Friis Møller blev nægtet tilladelse til en oplæsningsaften af Rudyard Kiplings Barrack Room Ballads, mens Emil Rasmussens Barbarkvinder, 1917 først blev stoppet efter i 6. oplag af være udkommet i 6.700 eksemplarer. Dette angiveligt humoristisk satiriske skrift mod krigen var i realiteten et forsvar for Tyskland, og da de kneb, forfatteren greb til, inkluderede fingerede beskrivelser af de hårrejsende seksuelle tilstande i Tyskland, lagt i munden på et - selvfølgeligt upålideligt - fransk vidne, kunne censuren slå til alene med henvisning til paragraf 184 og behøvede ikke at indrømme, at det i højere grad handlede om dansk udenrigspolitik.

Det blev anderledes åbenlyst i 1930'erne efter nazismens magtovertagelse i Tyskland. Aviserne blev bedt om at være afdæmpede i deres reportager om den store nabo mod syd, og tidsskrifter, som i ord og billeder bekæmpede fascisme og nazisme blev lagt hindringer i vejen. Det kortlivede antinazistiske tidsskrift Åndehullet 1933-34 blev uden at blive totalt forbudt udsat for statsmagtens chikane ved et forbud mod, at den blev solgt fra kiosker. Det skulle ødelægge det økonomiske grundlag for tidsskriftets eksistens - til behag for den nazistiske nabo. Da det ikke var nok, fik redaktøren, tegneren Hans Bendix, af Stauning valget mellem fortsat fast arbejde ved Social-Demokraten eller Aandehullet. Han valgte det faste arbejde, Aandehullet gik ind, men Bendix fortsatte sit antifascistiske virke.

Efter NATOs oprettelse og især i 1960'ernes atmosfære af sort/hvidt, dem/os, kapitalisme/kommunisme, hvor venstreorienterede angreb bl.a. USA's krig i Vietnam, udfoldedestatsmagten bestræbelser for at få gemytterne under kontrol gennem fortsatte aflytninger, kartoteker, infiltration og i enkelte tilfælde direkte forbud mod tryksager. Mest kendt er den såkaldte Kejsergadesag 1969, hvor det lille tidsskrift Vietnam-Solidaritet afslørede Politiets Efterretningstjenestes aflytning af østeuropæiske ambassader via en lyttecentral i Kejsergade. Denne anmasselse kunne man ikke så godt skride direkte ind overfor, men valgte så at slå ned på andre oplysninger om amerikanske militære installationer, som ganske vist var hentet fra helt åbne kilder, men dog kunne tjene som påskud for et forbud. Da påfølgende tidsskriftet Politisk Revy og dagbladet Information gengav de samme oplysninger, blev også de på hver deres måde ramt med sanktioner. 
R A D I O T A L E

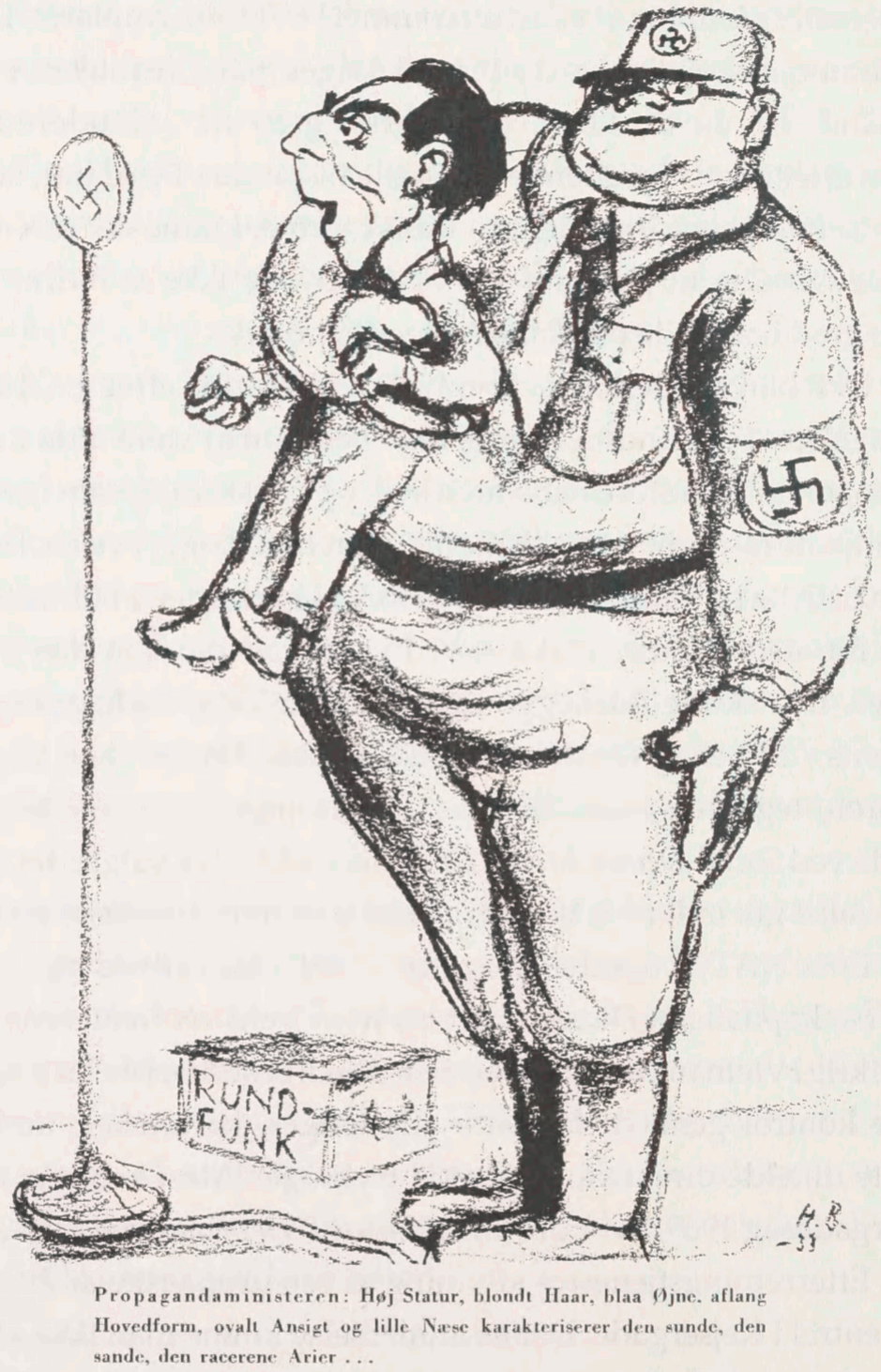

Aandehullet, hefte 1, oktober 1933, med Det tredie Riges propagandaminister i aktion - i Hans Bendix' streg. 
Den type forbud er et godt barometer for det politiske klima under skiftende internationale konjunkturer.

\section{Illegale blade, bøger og plakater}

Den tyske besættelse af Danmark 1940-1945 førte først til forbud mod udstilling og forhandling af en lang række danske og udenlandske værker, blandt hvilke skal nævnes alle bøger af Churchill og Marx (et sjældent makkerpar) og Erich Maria Remarque for hans antikrigsbøger om første verdenskrig; videreHartvig Frisch:Pest over Europa,1933, for dens antifascisme, Martin Andersen Nexø: To verdener, 1934 for den positive vurdering af Sovjetunionen, A.D. Stender-Petersen: Revolutionære profiler, 1933 for at vurdere de sovjetiske ledere sagligt, Francis Hackett: I chose Denmark, 1940 hvor alene titlen var en fornærmelse mod herrefolket.

Dette var endda til at håndtere, sværere var det med den øvrige censur og sværest med forbud mod kunstneriske udtryk. Det var ikke alle former for antinazisme, som afsløredes af tysk mentalitet. Ellers var tilladelsen af en sang som Man binder os på mund og hånd, tekst Poul Henningsen, sang Liva Weel, ikke mulig. Soya var ikke lige så heldig med sin roman En gæst, 1941, hvor et ubudent kryb i form af en ørentvist vokser til menneskestørrelse og overtager magten i det lille hyggelige borgerhjem. Parallellen til herrefolkets tilstedeværelse i Danmark var så åbenbar, at Soya kom i fængsel, og bogen blev forbudt - ved en dansk domstol.

En righoldig illegal litteratur sprang frem som konsekvens af den tyske censur. Illegale blade skrev, hvad aviserne ikke ville, kunne eller turde skrive. Illegale bøger udkom af forfattere og om emner, som ellers ikke ville kunne fremkomme under besættelsen. Det danskelune fornægtede sig heller ikke i den situation. Danske toner 1941 gav sig ud for et sanghæfte i nationalt udstyr med rød-hvide farver, men indholdt den eftersøgte kommunistiske partiformand, Aksel Larsens, tale til Folketinget, en tale som det høje tings grundlovsbrud (Kommunistloven 1941) hindrede ham i at holde. Det var vist kun tyskerne og den øvrige kommunistiske ledelse, som ikke syntes om den "musikalitet". Desværre kom de første omdelere af hæftet hurtigt til at "synge med" ved Københavns byret, idet de blev idømt fængsel.

Camouflering af illegale tryk ved at udgive dem for noget andet, 
blev en hel virksomhed for sig. Hvem vil vente at finde forbudte ord i Andagtsbog for Hjem og Skole (indeholdende Gustav Aulen: Kirken og Nationalsocialismen) eller i Håndbog i oversvømmelser, 1943 (bl.a. af Arne Sørensen) for slet ikke at tale om Koreplan udgivet af De danske Statsbaner (indeholdende Bomber over Tyskland). De vakte næppe umiddelbart mistænksomme politimænds eller Gestapofolks interesse, selv om de lå fremme på stuebordet. Og besiddelse af For Danmark mod Bolsjevismen i det Danske Regiment kunne ved sin lighed med Frikorps Danmarks hverveplakater kun vække sympati hos værnemagten og dens medløbere, hvis man ikke gik tættere på og læste på bagsiden, at den var trykt på "Forræderlandets Trykkeri".

Det kongelige Bibliotek får normalt via loven om pligtaflevering sine danske bøger og blade direkte fra bogtrykkerne. Illegale tryk var imidlertid i sagens natur ikke omfattet af loven (!), men i den i det hele taget meget velordnede og velorganiserede modstandskamp, fandt de illegale grupper efterhånden også ud af at sende eksemplarer af deres tryk til biblioteket. Her blev de gemt af vejen i magasinerne til bedre tider og kunne først lånes efter befrielsen. Under besættelsen kunne internerede lånere, som kommunisten og forfatteren Hans Kirk, derfor blandt meget andet heller ikke rekvirere den slags litteratur til Horserødlejren og Vestre Fængsel.

Gestapo fik nys om de illegale afleveringer og mødte op på biblioteket med krav om at få dem udleveret. Bibliotekar, dr.phil. Albert Fabritius havde spredt bladpakkerne forskellige steder så Gestapos udbytte var ringe, men bagefter var han heller ikke selv i stand til at erindre, hvor alle bladene var gemt. Derfor dukkede er helt frem til 1955 illegale bladpakker op!

Et værk produceret under besættelsen har opnået den tvivlsommeære at blive illegal efter befrielsen. Det er det såkaldte "Bovrup-Kartotek" indeholdende lister over en del af de mennesker, der på et tidspunkt i deres liv havde været medlem af DNSAP. Den blev udsendt af en gruppe, som var utilfreds med forløbet af retsopgøret. Domstolene greb straks ind for at hindre, at den publikation skulle blive et middel til at gøre det surt for alle med en nazistisk fortid.

\section{Forbudt pornografi}

Den litteratur, som fra starten ikke gav sig ud for at være andet end usminket 


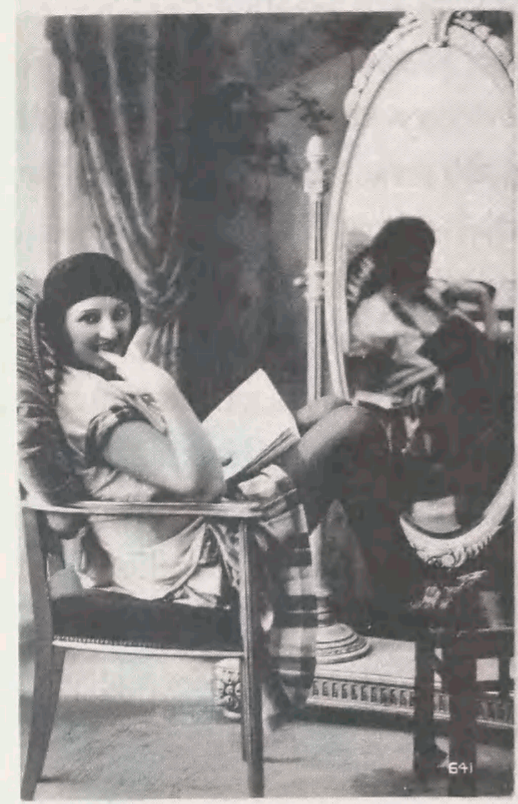

$\mathrm{X}$-Vej 2 ?

Kabenhs vn $a: 24 / 11$

Kinre Herre.

Idag skal les posbesunde den ny Rolx-

ke Breve, som Jeg har lovet Dell Do

som tee tror vil have Deres Interes.

8e. Tro inod mit tiducere Lofte.

skol jeg vare hensynsi, os erils of

fortaile Der alt; ja, selv det mest,

lintime of Ting, som jeg skaminer mik

over nan leg genorlever dem 1 crin-

oringen. Overfor Dein sket jeg intet-

gominelst fort $10, s e] \mathrm{V}$ om $j e 8$, nser

gominelst fortiver gile alsse for en KVin-

jes nedskive on pintlge Bnkel theder,

de ydmygende ob pinen fragag ken lef

mal rodine derved. somtidis bereder inis

like, at det son - Gren -

Der man vore noret 1 min Hatur,

Ser gor, it leg feler en solig, Ris-

len gennem kroppen ved at fole en

Illustration fra en maskinskrevet pornografisk udgivelse Evas Endefuld, Babys Have, Nye Bekendelser af en Dame af det gode Selskab, beslaglagt af Københavns Politi i 1937. (Pornografisamlingen).

pornografi, har indtil ophævelsen af forbudet mod pornografi den. 1. juli 1969 hele tiden eksisteret i illegaliteten, og kun en brøkdel af, hvad der har været i omløb, er kommet til retsvæsenets kendskab. Dansk pornografi i ældre tid, d.v.s. før anden verdenskrig, var ofte meget primitiv, til tider direkte hjemmelavet i få eksemplarer, skrevet på maskine og forsynet med enten billeder klippet ud fra andre kilder eller med private optagelser. De blev solgt under disken hos antikvarer og var særligt efterspurgte hos samlere for deres originalitet.

Efter krigen fandt pornografien flere og flere forlæggere, der var store penge at tjene ved industrialiseret produktion af blade og hæfter, hvilket gik hånd $\mathrm{i}$ hånd med krav om pornografiens frigivelse.

Den herskende kønsmoral aflæses bedst i blade og bøger, som har balanceret på kanten af forbudet. Set fra nutiden kan det være svært at erkende Eva. Illustreret Ugeblad $1877-88$ for så pikant i sit indhold og med sine simple tegninger, at det skulle overskride sømmelighedens grænser. Grotesk kan det også i dag forekomme, at en række hæfter af det seriøst oplysende 
tidsskrift Sex og Samfund 1937-38 blev forbudt som anstødelige.

I dag er kataloger fra stormagasiner som Magasin eller Daells, mere vovede (og raffinerede) i deres fremvisning af det nyeste i kvindelingeri end de lige tilladte blade for mænd var endnu i 1950'erne. Ofte var bladene let camouflerede som "kunstbøger", "modelstudier" eller "fotobøger" for den professionelle kunstner/fotograf. Der er næsten en lige linje til besættelsenstidens camouflerede tryk!

Med ophævelsen af forbudet mod pornografi kunne producenterne spare deres fantasi og anstrengelser med at skjule, hvor de fik deres produkter trykt. Det havde været et ofte anvendt fif at udgive pornografiske bøger og blade som trykt i udlandet, f. eks. Malmø, for at undgå repressalier mod trykkerierne. Efter pornoforbudets ophævelse kom en syndflod af porno der var ikke længere noget at skjule, men trods de fortsatte "anstrengelser", mærker man, at fantasien ikke er taget til hjælp.

\section{Danske svin}

Institutioner, virksomheder eller enkeltpersoner kan føle sig så forulempet af en udgivelse, at de ønsker den forbudt. Et karakteristisk eksempel er Preben Wencks to pjecer fra 1940 om den tyske besættelse 9. april 1940. De var meget ærerørige overfor den danske regering og specielt udenrigsminister P. Munch, som blev beskyldt for landsforræderi. På privat foranledning blev der nedlagt forbud mod pjecerne.

Kommercielle interesser kan også gøre sig gældende, som da forlaget Modtryk ikke kunne få lov til at genudgive romanen De hængtes revolution af B. Traven i 1977, fordi et andet forlag havde rettighederne og angiveligt ikke ønskede at få dette "socialistiske skidt" ud påny. På grund af både det politiske og principielle aspekt udgav Modtryk et optryk alligevel og blev ramt af forbud, fordi et andet forlags rettigheder blev krænket.

Fra de senere år er der en kuriøs sag, hvor et stort firma ikke ønskede sin Valo-reklamegengiveti et skolehæfte, somiøvrigthandledeom fascismens brug af billeder (1980). Ved retten søgte de forlaget dømt til at overstemple billedet, da det på misvisende måde kunne forbinde Valo med fascismen. Retten var af en anden mening, og dommeren gik i sine præmisser så vidt at rose hæftet højt! Det solgtes derefter med retsvæsenets anbefaling i 18.000 
eksemplarer.

Den mest kendte sag inden for de sidste 20 år, vedrører de danske svin. Allerede dette er jo flertydigt, for hvad sigtes der til? Multikunstneren Mikael Witte spillede effektfuldt på dette i 1970'erne i en stribe af samfundskritiske plakater og postkort, hvoraf en enkelt opnåede en helt sensationel gennemslagskraft. "Danske svin er sunde - de strutter af pencillin" stod der som tekst til en plakat af et dansk baconsvin. Det blev for meget for svineproducenterne. De fik den forbudt, angiveligt fordi den havde for meget lighed i tegningen med en af deres egne reklamer. Teksten blev ikke vurderet af domstolene. Forbudet bragte plakaten i alle medier, og det kom til en diskussion af både kunstnerisk frihed og svinekødets kvalitet. Sagen endte i Højesteret, som frikendte de "danske svin".

I dag hører forbud til de sjældne undtagelser. Strid om ophavsrettigheder og krænkelser af personers eller institutioners og virksomheders anseelse er som regel den primære grund til, at forbudte trykte ord og billeder ikke bliver ren historie.

Leif Blædel: Sagen om Fanny Hill. 1965. Elias Bredsdorff: Revolutionær humanisme, 1982.

Ole Ege: Erotiske drømme, 1992.

Max Iversen: Forbudte bøger.,1948. Torben Krogh: Anslag modstatens sikkerhed, 1971.
Helge Tønnesen:Camoufleredeillegale tryk. Fund og Forskning 5-6, 1958-59. Mette Winge: Omkring Håbløse Slægter, 1972.

Mikael Witte: Danske svin, 1980. 